\title{
Eicosapentaenoic acid and docosahexaenoic acid moderate inflammation in porcine cartilage explants
}

\author{
Cara I. Robison ${ }^{1}$ and Michael W. Orth ${ }^{2 *}$ \\ ${ }^{*}$ Correspondence: michael.orth@ttu.edu

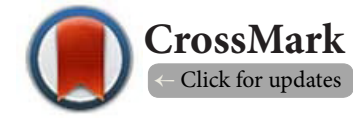 \\ 'Department of Animal Science, Michigan State University, 474 S. Shaw Lane, Anthony Hall Room 1290, East Lansing, MI, USA. \\ ${ }^{2}$ Department of Animal and Food Sciences, Texas Tech University, Box 42141, Lubbock, TX, USA.
}

\begin{abstract}
Objective: To characterize the effects of eicosapentaenoic acid (EPA) and docosahexaenoic acid (DHA) and arachidonic acid (ARA) in various combinations on indices of inflammation in recombinant porcine IL-1 beta stimulated porcine articular cartilage explants.

Methods: Cartilage was obtained from the humeral-ulnar joints of Yorkshire x Landrace market sized gilts. Explants were harvested from the humeral-ulnar joints within $8 \mathrm{~h}$ of slaughter. Explants were allocated to culture plates and cultured in $1 \mathrm{~mL}$ of Dulbecco's Modified Eagle serum free medium for $24 \mathrm{~h}$ with $10 \%$ fetal bovine serum. At 48 and $72 \mathrm{~h}, 1 \mathrm{~mL}$ of treatment media containing fatty acids and $15 \mathrm{ng} / \mathrm{mL}$ of recombinant porcine IL-1 was added to each well. At 48, 72, and $96 \mathrm{~h}$ after cartilage was allocated to wells, media were removed from each well and reserved for analysis. Media were analyzed for proteoglycan, nitric oxide (NO), interleukin-6 and prostaglandin $\mathrm{E}_{2}$ concentrations.

Results: In general, when EPA and/or DHA are supplemented to explants in combination with linoleic acid (LA) NO and prostaglandin $\mathrm{E}_{2}$ release is decreased. Explants treated with $25 \mu \mathrm{g} / \mathrm{mL}$ DHA released $53 \%$ less NO into the media than explants treated with the same level of EPA and $60 \%$ less than explants treated with LA alone.
\end{abstract}

Conclusions: These data demonstrate that EPA and DHA are capable of modulating the inflammatory response on porcine articular cartilage in vitro.

Keywords: Cartilage, omega-3, omega-6, fatty acids, swine

\section{Introduction}

Lameness is a common clinical condition in livestock usually resulting in culling of the affected animal. In livestock of all breeds this can be a cause of serious financial loss, including replacement cost, and is a source of major welfare concerns. Joint lesions have been identified as one of the main causes for culling sows in Danish herds, affecting $24 \%$ of sows [1], while in the U.S. $15.2 \%$ of sows are culled for locomotor problems [2]. Over a 6-month period, production sows culled for lameness were analyzed postmortem. It was found that 31 of the 45 sows were diagnosed with either osteochondrosis or athrosis [3].

The pathogenesis of osteoarthritis (OA) is strongly mediated

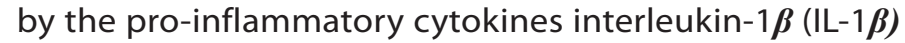
and tumor necrosis factor- $\alpha$ [4]. The inflammatory response in cartilage is regulated through cell signaling pathways that control gene expression of proteins responsible for the production of nitric oxide (NO), prostaglandin $\mathrm{E}_{2}\left(\mathrm{PGE}_{2}\right)$, and interleukin-6 (IL-6). Nitric oxide production plays a significant role in the development of cartilage degradation through inhibition of proteoglycan and collagen synthesis [5]. When cartilage is stimulated with IL-1 $\beta$ and/or tumor necrosis factor- $\boldsymbol{\alpha}$, increased NO production occurs. Mastbergen et al., [6] demonstrated that increased proteoglycan release from human articular cartilage is positively correlated with an increase in both NO and $\mathrm{PGE}_{2}$ production.

Omega-3 fatty acids have the potential to be potent modulators of osteoarthritic factors due to their ability to reduce prostaglandin and NO production. Eicosanoids formed from eicosapentaenoic acid (EPA) are 10- to 100-fold less potent than those produced from arachidonic acid (ARA) and therefore are associated with a decreased inflammatory response [7]. When mouse stromal cells were incubated with either $40 \mu \mathrm{M}$ ARA or 
EPA, ARA increased PGE 2 production, while EPA treated cells did not differ from the control. Additionally, Razzak et al., [8] demonstrated that when murine macrophages were incubated with lipopolysaccharide and a cyclooxygenase-2 (COX-2) inhibitor, NO production increased; however, when the same cells were incubated with EPA or a COX-2 inhibitor and EPA, NO production was minimal.

Both EPA and docosahexaenoic acid (DHA) can reduce the inflammatory response and the production of $\mathrm{NO}$ and $\mathrm{PGE}_{2}$ in other tissues. The objective of this study was to determine the concentration of EPA and DHA, both alone and in combination, necessary to reduce inflammatory mediators in porcine articular cartilage explants ex vivo relative to either linoleic acid (LA) or ARA.

\section{Materials and methods \\ Explant cultures}

Yorkshire $\mathrm{x}$ Landrace cross gilts were slaughtered at market weight following the standard practices of the MSU Meat Laboratory. For experiments 1 and 2, front legs were collected from 8 gilts, and for experiments 3 and 4, front legs were collected from 6 gilts. Front legs were removed within $30 \mathrm{~min}$ of slaughter. Each experiment was conducted separately. All chemicals were purchased from Sigma-Aldrich (St. Louis, MO, USA) unless otherwise specified.

The left and right humeral-ulnar joints were opened aseptically under sterile conditions and 50 cartilage disks were harvested with a $6 \mathrm{~mm}$ biopsy punch (Miltex, York, PA, USA) from the weight-bearing region of the articular surface of each gilt within $6 \mathrm{~h}$ of slaughter. Only visually normal cartilage was selected for biopsy.

Cartilage discs were washed twice in Dulbecco's modified Eagle's medium: nutrient mixture F-12 (Ham) (DMEM:F12; Invitrogen, Carlsbad, CA, USA) containing 100 units $/ \mathrm{mL}$ penicillin-streptomycin (Life Technologies, Carlsbad, CA, USA). Explant discs were randomly placed into the wells of a 24-well culture plate until each well contained two discs. Explants were conditioned for $24 \mathrm{~h}$ in $1 \mathrm{~mL}$ of base media, containing DMEM:F12 supplemented with amino acids [9], 10\% fetal bovine serum (FBS; Gibco, Invitrogen, Carlsbad, CA, USA), 50 $\mu \mathrm{g} / \mathrm{mL}$ ascorbate, and 100 units $/ \mathrm{mL}$ penicillin-streptomycin (Invitrogen, Carlsbad, CA, USA), in a humidified incubator at $37^{\circ} \mathrm{C}$ with $7 \% \mathrm{CO}_{2}$.

After $24 \mathrm{~h}$ of conditioning media explants were washed twice with $1 \mathrm{~mL}$ of sterile phosphate buffered saline to remove FBS from the wells. Saline was completely removed from each well after each wash. Then, $1 \mathrm{~mL}$ of treatment media consisting of FBS free base media plus $1 \mu \mathrm{L} / \mathrm{mL}$ insulintransferrin-sodium selenite supplement (Roche Applied Science, Mannheim, Germany), $0.02 \mu \mathrm{g} / \mathrm{mL}$ thyroxine, and long chain polyunsaturated fatty acids (LCPUFA; Camen Chemical, Ann Arbor, MI, USA) were added to each well (Table 1).

Each of the four experiments used a different combination of LCPUFA. Experiment 1 examined concentrations of EPA

Table 1. Detailed list of all experiments conducted, the concentration of IL-1 $\beta$, the control fatty acids.

\begin{tabular}{|c|c|c|c|c|c|c|}
\hline Experiment No. & Treatment & IL-1 $\beta, \mathrm{ng} / \mathrm{mL}$ & $\mathrm{LA}, \mu \mathrm{g} / \mathrm{mL}$ & $\mathrm{EPA}, \mu \mathrm{g} / \mathrm{mL}$ & $\mathrm{DHA}, \mu \mathrm{g} / \mathrm{mL}$ & $\mathrm{AA}, \mu \mathrm{g} / \mathrm{mL}$ \\
\hline \multirow[t]{5}{*}{1} & $100 \mathrm{LA}$ & 15 & 100 & 0 & -- & -- \\
\hline & 6.25 EPA & 15 & 93.75 & 6.25 & -- & -- \\
\hline & $12.5 \mathrm{EPA}$ & 15 & 87.5 & 12.5 & -- & -- \\
\hline & $18.75 \mathrm{EPA}$ & 15 & 81.25 & 18.75 & -- & -- \\
\hline & $25 \mathrm{EPA}$ & 15 & 75 & 25 & -- & -- \\
\hline \multirow[t]{5}{*}{2} & $100 \mathrm{LA}$ & 15 & 100 & -- & 0 & -- \\
\hline & $6.25 \mathrm{DHA}$ & 15 & 93.75 & -- & 6.25 & -- \\
\hline & $12.5 \mathrm{DHA}$ & 15 & 87.5 & -- & 12.5 & -- \\
\hline & $18.75 \mathrm{DHA}$ & 15 & 81.25 & -- & 18.75 & -- \\
\hline & 25 DHA & 15 & 75 & -- & 25 & -- \\
\hline \multirow[t]{6}{*}{3} & $100 \mathrm{LA}$ & 15 & 100 & 0 & 0 & -- \\
\hline & $25 \mathrm{EPA}$ & 15 & 75 & 25 & 0 & -- \\
\hline & $18 \mathrm{EPA}, 6 \mathrm{DHA}$ & 15 & 75 & 18.75 & 6.25 & -- \\
\hline & $12.5 \mathrm{EPA}, 12.5 \mathrm{DHA}$ & 15 & 75 & 12.5 & 12.5 & -- \\
\hline & $6 \mathrm{EPA}, 18 \mathrm{DHA}$ & 15 & 75 & 6.25 & 18.75 & -- \\
\hline & $25 \mathrm{DHA}$ & 15 & 75 & 0 & 25 & -- \\
\hline \multirow[t]{5}{*}{4} & $100 \mathrm{AA}$ & 15 & -- & 0 & 0 & 100 \\
\hline & $12.5 \mathrm{EPA}$ & 15 & -- & 12.5 & 0 & 87.5 \\
\hline & $25 \mathrm{EPA}$ & 15 & -- & 25 & 0 & 75 \\
\hline & $12.5 \mathrm{DHA}$ & 15 & -- & 0 & 12.5 & 87.5 \\
\hline & $25 \mathrm{DHA}$ & 15 & -- & 0 & 25 & 75 \\
\hline
\end{tabular}

linoleic acid (LA) and arachidonic acid (AA) as well as the treatment fatty acids: eicosapentaenoic acid (EPA) and docosahexaenoic acid (DHA) for each treatment. 
varying from 0 to $25 \mu \mathrm{g} / \mathrm{mL}$ with LA added to total $100 \mu \mathrm{g} /$ $\mathrm{mL}$ of total fatty acids in the media. Experiment 2 examined concentrations of DHA varying from 0 to $25 \mu \mathrm{g} / \mathrm{mL}$ with LA added to total $100 \mu \mathrm{g} / \mathrm{mL}$ of total fatty acids in the media. Experiment 3 examined EPA and DHA at the following concentrations: $25 \mu \mathrm{g} / \mathrm{mL}$ EPA, $18.75 \mu \mathrm{g} / \mathrm{mL}$ EPA with 6.25 $\mu \mathrm{g} / \mathrm{mL}$ DHA, $12.5 \mu \mathrm{g} / \mathrm{mL}$ EPA with $12.5 \mu \mathrm{g} / \mathrm{mL}$ DHA, 6.25 $\mu \mathrm{g} / \mathrm{mL}$ EPA with $18.75 \mu \mathrm{g} / \mathrm{mL} \mathrm{DHA}$, and $25 \mu \mathrm{g} / \mathrm{mL}$ DHA. The control treatment contained $100 \mu \mathrm{g} / \mathrm{mL}$ LA while all other treatments contained $75 \mu \mathrm{g} / \mathrm{mL}$ LA in addition to the EPA and DHA. Experiment 4 examined either EPA or DHA at the following concentrations: $12.5 \mu \mathrm{g} / \mathrm{mL}$ EPA, $25 \mu \mathrm{g} / \mathrm{mL}$ EPA, 12.5 $\mu \mathrm{g} / \mathrm{mL} \mathrm{DHA}, 25 \mu \mathrm{g} / \mathrm{mL}$ DHA. The control treatment contained $100 \mu \mathrm{g} / \mathrm{mL}$ ARA while all other treatments contained ARA at either $87.5 \mu \mathrm{g} / \mathrm{mL}$ or $75 \mu \mathrm{g} / \mathrm{mL}$ to total $100 \mu \mathrm{g} / \mathrm{mL}$ fatty acids in the media. Fatty acid concentrations used in these four experiments were based two factors. First, a preliminary study in which concentrations of $0,25,50,75$, and $100 \mu \mathrm{g} / \mathrm{mL}$ EPA were tested and it was determined that concentrations of EPA over $25 \mu \mathrm{g} / \mathrm{mL}$ provided no additional advantage. Second, LCPUFA concentrations less than $25 \mu \mathrm{g} / \mathrm{mL}$ are likely more biologically relevant.

At 48 and $72 \mathrm{~h} 15 \mathrm{ng} / \mathrm{mL}$ of recombinant porcine IL-1 $\beta$ ( $R$ \& D Systems, Minneapolis, MN, USA) were added to the treatment media (Figure 1). Between 24 and $48 \mathrm{~h}$ the explants were not exposed to IL- $1 \beta$ to serve as the unstimulated control. At 48,72 , and $96 \mathrm{~h}$ media were removed from each well and separated into two tubes for analysis. The first tube contained $10 \mu \mathrm{g} / \mathrm{mL}$ indomethacin to prevent further metabolism of $\mathrm{PGE}_{2}$ and was stored at $-20^{\circ} \mathrm{C}$ until analysis. The second tube did not contain any additives and was stored at $4^{\circ} \mathrm{C}$ for $\mathrm{NO}$ and proteoglycan analysis. Media were analyzed for proteoglycans (PG), NO, interleukin-6 (IL-6), and PGE ${ }_{2}$ concentrations.

\section{Proteoglycan analysis}

Proteoglycan release into media was measured using the dimethylmethylene blue assay [10]. Proteoglycan content was determined by measuring sulfated glycosaminoglycan content using a chondroitin sulfate standard and expressed as $\mu \mathrm{g}$ PG/well. Absorbance at $530 \mathrm{~nm}$ with a correction at $590 \mathrm{~nm}$ was determined using a Spectramax 300 plate reader (Molecular Devices, Sunnyvale, CA, USA).

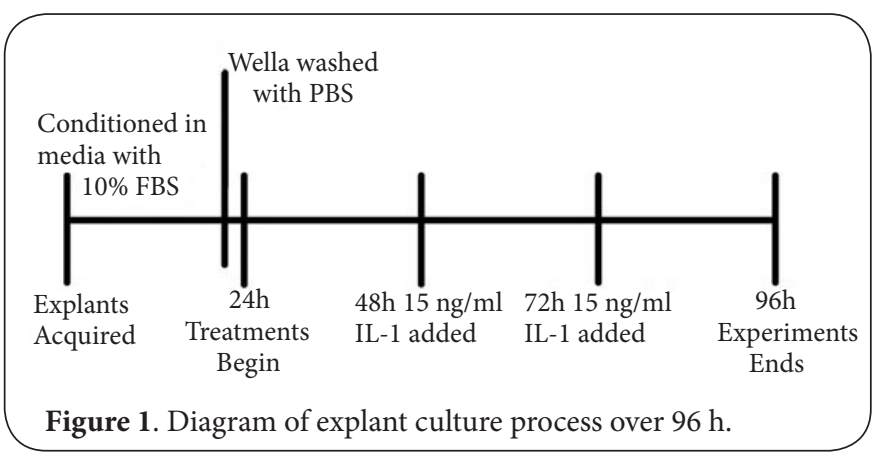

\section{Nitric oxide analysis}

Nitric oxide was measured indirectly by quantifying nitrite, a stable end-product of nitric oxide metabolism, in the media by using the Greiss reaction and a sodium nitrite standard [11]. Absorbance at $540 \mathrm{~nm}$ was determined using a Spectramax 300 plate reader (Molecular Devices, Sunnyvale, CA, USA). Results are expressed as $\mu \mathrm{M}$ of NO/well.

\section{Prostaglandin $\mathrm{E}_{2}$ analysis}

Prostaglandin $\mathrm{E}_{2}$ was measured in the media using a commercially available ELISA kit(EHPGE2; Thermo-Fisher Scientific, Pittsburgh, PA, USA) following the manufacturer's instructions. Media samples were diluted as needed in the provided assay buffer and analyzed. Absorbance at $405 \mathrm{~nm}$ with a correction at $580 \mathrm{~nm}$ was determined using a Spectramax 300 plate reader (Molecular Devices, Sunnyvale, CA, USA).

\section{Interleukin- $\mathbf{6}$ analysis}

Interleukin- 6 was measured in the media using a porcinespecific, commercially available ELISA kit (Porcine IL-6 Duoset; DY686, R \& D Systems, Minneapolis, MN, USA) following the manufacturer's instructions. Samples were diluted as needed in the reagent diluent and analyzed in duplicate. Absorbance at $450 \mathrm{~nm}$ with a correction at $570 \mathrm{~nm}$ was determined using a Spectramax 300 plate reader (Molecular Devices, Sunnyvale, (A, USA).

\section{Statistical analysis}

Data were analyzed as a cumulative response following stimulation with IL-1, such that the response from media collected at $72 \mathrm{~h}$ was added to the response from media collected at $96 \mathrm{~h}$. Data were analyzed using the mixed procedure of SAS (version 9.2; SAS Inst. Inc., Cary, NC, USA) with animal, treatment and time in the model. A random statement of animal nested in treatment was used. Differences between means were examined using the pdiff function. All data will be presented as Ismeans \pm SEM. P-values $<0.05$ will be discussed as significant while P-values $<0.10$ will be discussed as trends.

\section{Results}

Prior to IL-1 $\beta$ stimulation, release of proteoglycans, and production of nitric oxide and IL- 6 did not exhibit a treatment effect for any of the 4 experiments. Additionally, experiments 1 and 3 did not exhibit a treatment effect for $\mathrm{PGE}_{2}$ production prior to IL-1 $\beta$ stimulation. In experiment 2, explants treated with 12.5 and $25 \mu \mathrm{g} / \mathrm{mL}$ of DHA produced more $\mathrm{PGE}_{2}$ prior to stimulation than those treated with $100 \mu \mathrm{g} / \mathrm{mL}$ of LNA, 6.25 $\mu \mathrm{g} / \mathrm{mL}$ of DHA and $18.75 \mu \mathrm{g} / \mathrm{mL}$ of DHA (P<0.01; Table 3). In experiment 4 , where ARA was used as the control fatty acid, prior to IL-1 $\beta$ stimulation the control produced 1.7 times more $\mathrm{PGE}_{2}$ than the next highest treatment while the $25 \mu \mathrm{g} / \mathrm{mL}$ of DHA produced the least amount of $\mathrm{PGE}_{2}(\mathrm{P}<0.01$; Table 5$)$.

Cartilage explants treated with 0 to $25 \mu \mathrm{g} / \mathrm{mL}$ of EPA and stimulated with IL-1 $\beta$ exhibited a trend for an overall effect of 
treatment $(P=0.09)$ in which the 6.25 and 12.5 EPA treatments released less proteoglycans than 100 LA or 18.75 EPA (Table 2; $\mathrm{P}<0.05, \mathrm{P}=0.07$ ). Proteoglycan release from cartilage explants treated with 0 to $25 \mu \mathrm{g} / \mathrm{mL}$ of DHA or 0 to $25 \mu \mathrm{g} / \mathrm{mL}$ of EPA and DHA and stimulated with IL-1 $\beta$ displayed no difference in cumulative release over $48 \mathrm{~h}$ (Tables 3 and 4). Post IL-1 $\beta$ stimulation, explants with ARA as the control fatty acid and treated with 12.5 or $25 \mu \mathrm{g} / \mathrm{mL}$ of EPA released more proteoglycans than those treated with 12.5 and $25 \mu \mathrm{g} / \mathrm{mL}$ of DHA (Table 5).

There was no difference in nitric oxide release from explants treated with varying concentrations of EPA and stimulated with IL-1 $\beta(P<0.05)$. Explants treated with DHA displayed an overall effect of treatment $(P<0.01)$ and at $72 \mathrm{~h}$ the $12.5,18.75$ and $25 \mathrm{DHA}$ treatments released less $\mathrm{NO}$ than the $100 \mathrm{LA}$ or the 6.25 DHA (Table 3). In explants treated with EPA and DHA alone or in combination $\mathrm{NO}$ release exhibited an overall effect of treatment $(\mathrm{P}<0.01)$ and all fatty acid treatments released less NO than the 100 LA treatment $(P<0.05$; Table 4 and Figure 2$)$. Additionally, the $25 \mathrm{DHA}$ treatment in experiment 3 released less NO than any other treatment $(P<0.01)$. Explants with ARA as the control fatty acid exhibited a treatment effect for $\mathrm{NO}$ release with the $25 \mu \mathrm{g} / \mathrm{mL}$ of EPA treatment releasing the most NO $(\mathrm{P}<0.01$; Table 5$)$ while there was no difference between the control, 12.5 DHA and 25 DHA treatments.

Prostaglandin $\mathrm{E}_{2}$ release was not affected by treatment with EPA and stimulation with IL-1 $\beta$ in experiment 1 (Table 2). In experiments 2 and $3, \mathrm{PGE}_{2}$ release exhibited an overall effect

Table 2. Cumulative proteoglycan(PG), nitric oxide (NO), prostaglandin $E_{2}$ $\left(\mathrm{PGE}_{2}\right.$ ), and interleukin-6 (IL-6) release from cartilage into media for experiment 1 when explants were treated with 0 to $25 \mu \mathrm{g} / \mathrm{mL}$ of eicosapentaenoic acid (EPA) (Table 1). Proteoglycan release exhibited trend for a treatment effect $(\mathrm{P}=\mathbf{0 . 0 8 7})$. Means with different letters differ $(\mathbf{P}<0.05)$ for a given analyte.

\begin{tabular}{llllllll}
\hline & 100 LA & $\mathbf{6 . 2 5}$ EPA & $\mathbf{1 2 . 5}$ EPA & $\mathbf{1 8 . 7 5}$ EPA & 25 EPA & SEM & P-value \\
\hline PG & & & & & & & \\
Pre IL-1 & 101.9 & 101.0 & 122.8 & 96.8 & 103.9 & 18.4 & 0.872 \\
Post IL-1 & $540.1^{\mathrm{a}}$ & $423.2^{\mathrm{b}}$ & $452.8^{\mathrm{ab}}$ & $526.2^{\mathrm{a}}$ & $478.7^{\mathrm{ab}}$ & 32.8 & 0.087 \\
\hline NO & & & & & & & \\
Pre IL-1 & 15.7 & 15.2 & 14.9 & 15.5 & 14.8 & 0.58 & 0.795 \\
Post IL-1 & 86.7 & 77.6 & 74.7 & 80.9 & 76.1 & 3.9 & 0.228 \\
\hline PGE & & & & & & & \\
Pre IL-1 $_{1} 84.0$ & 92.4 & 71.06 & 103.7 & 112.8 & 19.7 & 0.584 \\
Post IL-1 & 917.5 & 903.3 & 486.3 & 865.1 & 640.4 & 177 & 0.346 \\
\hline IL-6 & & & & & & & \\
Pre Il-1 & 63.2 & 55.9 & 34.39 & 36.0 & 44.8 & 11.5 & 0.323 \\
Post IL-1 & 6390.3 & 6059.0 & 6475.7 & 6194.7 & 6419.5 & 724 & 0.993 \\
\hline
\end{tabular}

Table 3. Cumulative proteoglycan (PG), nitric oxide (NO), prostaglandin $\mathrm{E}_{2}$ $\left(\mathrm{PGE}_{2}\right.$ ), and interleukin-6 (IL-6) release from cartilage into media for experiment 2 when explants were treated with 0 to $25 \mu \mathrm{g} / \mathrm{mL}$ of docosahexaenoic acid (DHA) (Table 1). NO and $\mathrm{PGE}_{2}$ release exhibited a treatment effect $(\mathrm{P}<0.01)$. Means with different letters differ $(\mathbf{P}<\mathbf{0 . 0 5})$ for a given analyte.

\begin{tabular}{llllllll}
\hline & 100 LA & $\mathbf{6 . 2 5}$ DHA & 12.5 DHA & 18.75 DHA & 25 DHA & SEM & P-value \\
\hline PG & & & & & & & \\
Pre IL-1 & 70.2 & 71.1 & 66.6 & 72.2 & 75.8 & 5.3 & 0.81 \\
Post IL-1 & 380.7 & 347.9 & 282.8 & 298.0 & 312.3 & 34.7 & 0.285 \\
\hline NO & & & & & & & \\
Pre IL-1 & 14.3 & 14.5 & 13.9 & 13.0 & 12.3 & 0.8 & 0.270 \\
Post IL-1 & $74.7^{\mathrm{a}}$ & $66.12^{\mathrm{a}}$ & $52.05^{\mathrm{b}}$ & $52.75^{\mathrm{b}}$ & $46.58^{\mathrm{b}}$ & 4.8 & 0.001 \\
\hline PGE & & & & & & & \\
Pre IL-1 & $22.3^{\mathrm{a}}$ & $39.3^{\mathrm{ab}}$ & $153.0^{\mathrm{c}}$ & $56.3^{\mathrm{a}}$ & $104.7^{\mathrm{bc}}$ & 24.3 & 0.008 \\
Post IL-1 & $1060.1^{\mathrm{a}}$ & $431.2^{\mathrm{b}}$ & $523.2^{\mathrm{b}}$ & $382.3^{\mathrm{b}}$ & $474.9^{\mathrm{b}}$ & 102 & $<0.001$ \\
\hline IL-6 & & & & & & & \\
Pre IL-1 & 42.7 & 43.3 & 19.0 & 13.4 & 7.1 & 21.6 & 0.66 \\
Post IL-1 & 3923.3 & 4380.1 & 3446.5 & 3844.1 & 3642.7 & 938 & 0.967 \\
\hline
\end{tabular}


Table 4. Cumulative proteoglycan (PG), nitric oxide (NO), prostaglandin $\mathrm{E}_{2}\left(\mathrm{PGE}_{2}\right)$, and interleukin-6 (IL-6) release from cartilage into media for experiment 3 when explants were treated with 0 to $25 \mu \mathrm{g} / \mathrm{mL}$ of eicosapentaenoic acid (EPA) and docosahexaenoic acid (DHA)alone or in combination (Table 1). NO and $\mathrm{PGE}_{2}$ release exhibited a treatment effect $(\mathrm{P}<0.01)$ post interleukin-1 (IL-1) stimulation. Means with different letters differ $(P<0.05)$ for a given analyte.

\begin{tabular}{|c|c|c|c|c|c|c|c|c|}
\hline & $100 \mathrm{LA}$ & 25 EPA & 18.75 EPA, 6.25 DHA & 12.5 EPA, 12.5 DHA & 6.25 EPA, 18.75 DHA & 25 DHA & SEM & P-value \\
\hline \multicolumn{9}{|l|}{ PG } \\
\hline Pre IL-1 & 66.1 & 62.8 & 68.2 & 69.6 & 65.5 & 65.1 & 4.92 & 0.941 \\
\hline Post IL-1 & 473.7 & 427.7 & 383.4 & 478.5 & 386.1 & 352.5 & 40.7 & 0.189 \\
\hline \multicolumn{9}{|c|}{$\mathrm{NO}$} \\
\hline Pre IL-1 & 13.5 & 12.6 & 12.6 & 12.0 & 11.8 & 12.1 & 1.4 & 0.963 \\
\hline Post IL-1 & $72.7^{\mathrm{a}}$ & $59.1^{\mathrm{b}}$ & $52.54^{\mathrm{b}}$ & $54.7^{\mathrm{bc}}$ & $47.72^{\mathrm{c}}$ & $28.5^{\mathrm{d}}$ & 3.6 & $<0.001$ \\
\hline \multicolumn{9}{|c|}{$\mathrm{PGE}_{2}$} \\
\hline Pre IL-1 & 91.0 & 222.0 & 292.7 & 235.3 & 218.5 & 376.8 & 87.44 & 0.302 \\
\hline Post IL-1 & $1379.8^{\mathrm{a}}$ & $578.2^{\mathrm{b}}$ & $471.7^{\mathrm{b}}$ & $521.8^{\mathrm{b}}$ & $357.1^{\mathrm{b}}$ & $641.9^{b}$ & 149.8 & 0.001 \\
\hline \multicolumn{9}{|c|}{ IL-6 } \\
\hline Pre IL-1 & 25.5 & 120.5 & 28.4 & 145.4 & 114.0 & 38.4 & 57.95 & 0.529 \\
\hline Post IL-1 & 6830.8 & 9870.4 & 10172 & 12468 & 7255.2 & 6852.9 & 1768 & 0.163 \\
\hline
\end{tabular}

Table 5. Cumulative proteoglycan (PG), nitric oxide (NO), prostaglandin $\mathrm{E}_{2}\left(\mathrm{PGE}_{2}\right)$, and interleukin-6 (IL-6) release from cartilage into media for experiment 4 when explants were treated with 12.5 or $25 \mu \mathrm{g} / \mathrm{mL}$ of eicosapentaenoic acid (EPA) and docosahexaenoic acid (DHA) (Table 1). All variables exhibited a treatment effect post interleukin-1 (IL-1) stimulation $(P<0.01)$. Means with different letters differ $(P<0.05)$ for a given analyte.

\begin{tabular}{|c|c|c|c|c|c|c|c|}
\hline & $100 \mathrm{AA}$ & 12.5 EPA & 25 EPA & 12.5 DHA & 25 DHA & SEM & P-value \\
\hline \multicolumn{8}{|l|}{ PG } \\
\hline Pre IL-1 & 60.9 & 64.5 & 78.8 & 57.9 & 61.4 & 6.0 & 0.125 \\
\hline Post IL-1 & $126.6^{\mathrm{ac}}$ & $208.3^{\mathrm{b}}$ & $230.8^{\mathrm{b}}$ & $152.2^{\mathrm{a}}$ & $96.6^{c}$ & 16.6 & $<0.001$ \\
\hline \multicolumn{8}{|l|}{ NO } \\
\hline Pre IL-1 & 6.9 & 7.0 & 4.0 & 7.0 & 4.1 & 1.7 & 0.471 \\
\hline Post IL-1 & $9.2^{\mathrm{a}}$ & $17.4^{\mathrm{b}}$ & $21.8^{\mathrm{c}}$ & $10.0^{\mathrm{ad}}$ & $8.9^{\text {ad }}$ & 1.3 & $<0.001$ \\
\hline \multicolumn{8}{|l|}{$\mathrm{PGE}_{2}$} \\
\hline Pre IL-1 & $34695^{\mathrm{a}}$ & $20240^{\mathrm{b}}$ & $11180^{\mathrm{bc}}$ & $19880^{\mathrm{b}}$ & $8680^{c}$ & 3304 & $<0.001$ \\
\hline Post IL-1 & $122110^{\mathrm{a}}$ & $76420^{\mathrm{b}}$ & $30290^{c}$ & $80135^{\mathrm{b}}$ & $81670^{\mathrm{b}}$ & 7080 & $<0.001$ \\
\hline \multicolumn{8}{|l|}{ IL-6 } \\
\hline Pre IL-1 & 1.8 & 3.7 & 1.7 & 2.3 & 2.4 & 1.5 & 0.884 \\
\hline Post IL-1 & $585.8^{\mathrm{a}}$ & $2287.6^{b}$ & $4136.4^{c}$ & $2309.5^{b}$ & $238.7^{a}$ & 601.1 & $<0.001$ \\
\hline
\end{tabular}

of treatment $(\mathrm{P}<0.01)$ in which all EPA and/or DHA treatments decreased release when compared to the control $(P<0.05$; Table 3 and Figure 3 ) with no difference between the fatty acid treatments. Cumulative release of $\mathrm{PGE}_{2}$ in experiment 4 was also affected by treatment $(P<0.01)$ with the $25 \mathrm{EPA}$ treatment producing the least amount of $\mathrm{PGE}_{2}$ and the ARA control treatment producing the most $(\mathrm{P}<0.01$; Table 5$)$.

Experiments 1, 2, and 3 did not have any effect on IL-6 release into the media regardless of fatty acid or concentration. However, experiment 4 demonstrated that cumulative release of IL- 6 was affected by treatment $(P<0.01)$ such that the 25 $\mu \mathrm{g} / \mathrm{mL}$ of EPA treatment produced $50 \%$ more than the 12.5 EPA and DHA treatments and $86 \%$ more than the 100 ARA or 25 DHA treatments $(P<0.01$; Table 5$)$.

\section{Discussion and conclusion}

This work investigated the anti-inflammatory effects of EPA and DHA by measuring inflammatory mediators and tissue degradation in a porcine explant model of inflammatory joint disease. The in vitro system of cartilage explants does mimic physiological conditions. The experiments were designed to determine the potential for omega- 3 fatty acids to influence inflammatory molecules in porcine cartilage. Supplementation of EPA and/or DHA into porcine explant cultures consistently caused a reduction in $\mathrm{NO}$ and $\mathrm{PGE}_{2}$ concentrations in the media; however, only EPA alone was able to alter PG release. In previous studies, II- $1 \beta$ has been successfully used to induce cartilage degradation [12-14]. DHA was successful at altering chondrocyte metabolism to inhibit $\mathrm{NO}$ and $\mathrm{PGE}_{2}$ production. 


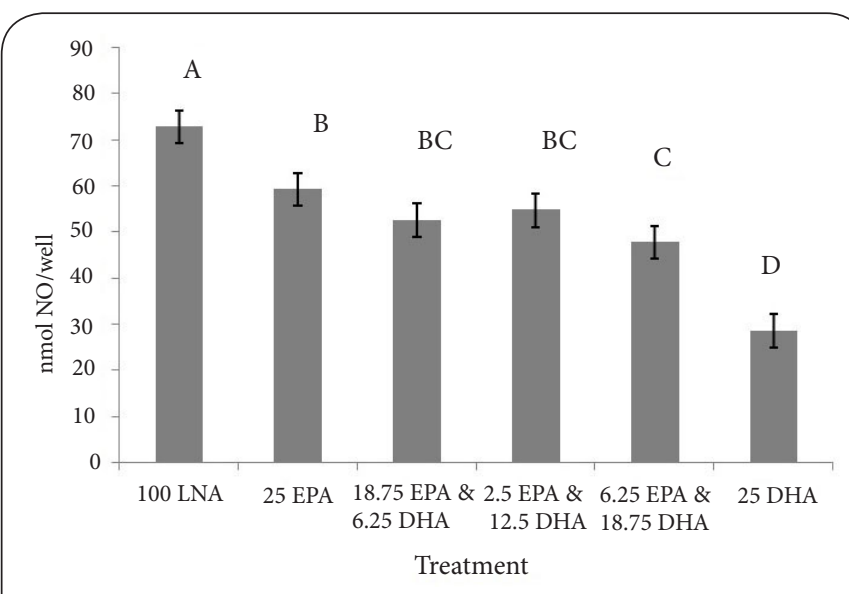

Figure 2. Cumulative nitric oxide (NO) release from cartilage into media for Experiment 3 when explants were treated with 0 to $25 \mu \mathrm{g} / \mathrm{mL}$ of eicosapentaenoic acid (EPA) and docosahexaenoic acid (DHA)alone or in combination (Table 1). NO exhibited a treatment effect $(\mathrm{P}<0.01)$. Bars with different letters differ at $\mathrm{P}<0.05$.

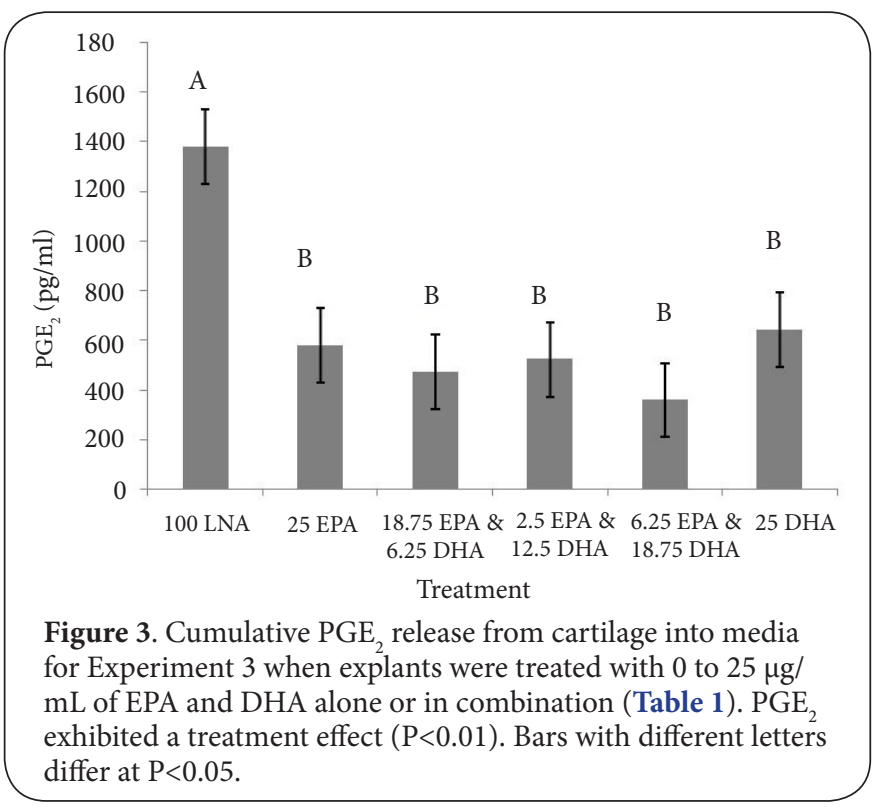

The reduction in NO is likely due to a concurrent reduction in $\mathrm{PGE}_{2}$.

Omega-3 fatty acids are known for their anti-inflammatory properties with a reduction in $\mathrm{PGE}_{2}$ being a consistent finding regardless of tissue. Arachidonic acid is an omega- 6 fatty acid, which generally initiates a pro-inflammatory response via its metabolism to $\mathrm{PGE}_{2}$ in the cell. Arachidonic acid is the preferred substrate for COX-2; however, EPA can also be used. In vitro COX-2 has higher specificity for ARA than for EPA and preferentially oxygenates ARA when both fatty acids are present even if ARA is at a low substrate concentration [15]. In the current experiments, when only EPA or DHA and LA were present in the media, once all ARA was released from the cellular membrane any additional reactions would utilize EPA as a substrate for COX-2, resulting in the production of $\mathrm{PGE}_{3}$. Since the ELISA used in the current study to measure the concentration of $\mathrm{PGE}_{2}$ in the media has minimal cross reactivity with $P G E_{3}$ the lower concentration of $\mathrm{PGE}_{2}$ in the EPA-treated media may be due to the production of $\mathrm{PGE}_{3}$ and not alterations in COX-2 expression. In experiment 4 when ARA was present in the media as the control fatty acid instead of LA the PGE levels were 122 times higher after IL-1 $\beta$ stimulation than in the LA treatment of the other experiments. Addition of EPA or $\mathrm{DHA}$ at any level was sufficient to reduce $\mathrm{PGE}_{2}$ production even with an unlimited supply of ARA; however the $25 \mathrm{EPA}$ treatment was able to create the most substantial reduction of approximately $75 \%$. In the experiments using LA as the control, the presence of either EPA or DHA at any concentration or combination reduced $\mathrm{PGE}_{2}$ concentrations similarly. The data from experiment 4 suggests that EPA may be utilizing competitive inhibition with ARA while DHA may beregulating COX-2 at a molecular level to reduce the production of $\mathrm{PGE}_{2}$ post-stimulation.

In addition to a reduction in $\mathrm{PGE}_{2}$, supplementation of EPA and/or DHA resulted in the reduction of NO production. Nitric oxide production plays a significant role in the development of cartilage degradation through inhibition of proteoglycan and collagen synthesis [5]. Mastbergen et al., [6] demonstrated that increased proteoglycan release from human articular cartilage is positively correlated with an increase in both $\mathrm{NO}$ and $\mathrm{PGE}_{2}$ production. Cyclooxygenase-2, inducible nitric oxide synthase (iNOS), and fatty acids have a very complicated interrelationship that has been explored by many researchers in various cell types $[\mathbf{8 , 1 6 - 1 8 ]}$. For example, when ARA was added to osteoblast cell cultures an increase in iNOS gene expression occurred; however, when EPA was added to ARAtreated cells, EPA prevented an increase in iNOS expression [16]. This suggests that EPA may be a more potent regulator of iNOS expression than ARA. However, when ARA was used as the control fatty acid NO production increased when EPA was added to the wells. Little research has been conducted using chondrocytes and it is possible that other cell types respond differently under these conditions.

Mouse macrophages treated with $60 \mu \mathrm{M}$ of LA, LNA, ARA, EPA, or DHA and stimulated with lipopolysaccharide and interferon- $\gamma$ to simulate a bacterial endotoxin demonstrated that both EPA and DHA inhibited NO production, while only DHA inhibited iNOS protein and mRNA expression [17]. This suggests that in vitro DHA is a more potent regulator of $\mathrm{NO}$ and $P G E$, release than $E P A$, which agrees with our results. This is likely due to the difference in the mechanisms by which each of these fatty acids regulate the inflammatory mediators at a molecular level. Razzak et al., [8] demonstrated that when murine macrophages were incubated with lipopolysaccharide (LPS) and a COX-2 inhibitor, NO production increased. However, when the same cells were incubated with EPA or a COX-2 
inhibitor and EPA, NO production was minimal. The authors attributed this decrease in NO production to a series of omega-3 fatty acid related, multi-factorial events involving iNOS and COX-2.

When DHA was added in conjunction with LA similar results were found as when EPA was used. When either EPA or DHA was added in conjunction with ARA only the 25 DHA treatment was able to reduce NO production; all other treatments produced NO concentrations higher than the control. This suggests that EPA and DHA are not working through the same pathways. EPA, DHA, and LNA are potent inhibitors of COX-2 catalyzed prostaglandin biosynthesis in in vitro studies [18]. In activated macrophages the transcription factor NF-KB must be activated for iNOS gene expression. When macrophages were supplemented with DHA the amount of NF-KB binding decreased, thus inhibiting both iNOS expression and NO production [17]. In vascular endothelial cell cultures, when cells were exposed to $25 \mu \mathrm{mol} / \mathrm{L}$ DHA for $48 \mathrm{~h}$ before exposure to $10 \mathrm{ng} / \mathrm{mL} \mathrm{IL-1a}$, inhibition of COX-2 increased greater than $50 \%$ [19]. Following a series of experiments in which endothelial cells were incubated with $25 \mu \mathrm{mol} / \mathrm{L} \mathrm{DHA}$ for $48 \mathrm{~h}$ the researchers concluded that DHA inhibits COX-2 expression through two mechanisms. First, DHA reducesprotein kinase $\mathrm{C}$-Eactivation thereby inhibiting $\mathrm{COX}-2$ and $\mathrm{NOS}$ gene expression. Secondly, DHA scavenges reactive oxygen species preventing the production of $\mathrm{H}_{2} \mathrm{O}_{2}$, which is necessary for nuclear factor kappa-light-chain-enhancer of $\mathrm{B}$ cells activation [19]. DHA should interface with IL-1 signaling pathways in a similar manner regardless of tissue type, therefore reduction in NF-KB activation can explain the decrease in both $\mathrm{NO}$ and $\mathrm{PGE}_{2}$ production in $\mathrm{DHA}$ treated cell cultures since both iNOS and $\mathrm{COX}-2$ require NF-KB activation.

The ability of EPA and DHA to alter inflammatory mediators depends highly on the incorporation of these fatty acids into the cell membrane. Dietary omega-3 fatty acids are preferentially incorporated into certain tissues. DHA content in plasma, liver, brain, and other organs is highly correlated to erythrocyte DHA levels [20]. A suitable biomarker that correlates with EPA and DHA status in articular tissue has not been identified. At the in vivo level the concern would be whether or not sufficient levels of EPA and/or DHA could be obtained in the cartilage to elicit the reduction in inflammatory mediators. Dietary supplementation of $1 \%$ protected fish oil increases the DHA concentration in the cartilage of sows 2.4 fold when compared to a control diet when fed for an average of 2 years [21]. Additionally, synovial fluid concentrations of EPA and DHA were higher in sows fed protected fish oil as $1 \%$ of their diet [21]. Although the aforementioned study measured increased concentrations of DHA in the cartilage following fish oil supplementation the changes may not have been substantial enough to be biologically significant.

These data provide evidence that both EPA and DHA are able to alter the production of $\mathrm{NO}$ and $\mathrm{PGE}_{2}$ in porcine articular cartilage explants. Further research is necessary to more precisely explain the mechanisms by which EPA is altering $\mathrm{PGE}_{2}$ production and $\mathrm{DHA}$ is altering the production of $\mathrm{NO}$. Additionally, it has yet to be determined if EPA and DHA can be added to a porcine diet at a concentration that will modulate articular cartilage metabolism without adversely impacting other physiological processes in the animal.

\section{Competing interests}

The authors declare that they have no competing interests.

Authors' contributions

\begin{tabular}{|l|c|c|}
\hline Authors' contributions & CIR & MWO \\
\hline Research concept and design & $\checkmark$ & $\checkmark$ \\
\hline Collection and/or assembly of data & $\checkmark$ & -- \\
\hline Data analysis and interpretation & $\checkmark$ & $\checkmark$ \\
\hline Writing the article & $\checkmark$ & -- \\
\hline Critical revision of the article & -- & $\checkmark$ \\
\hline Final approval of article & $\checkmark$ & $\checkmark$ \\
\hline Statistical analysis & $\checkmark$ & -- \\
\hline
\end{tabular}

\section{Acknowledgement}

The authors would like to thank the Michigan State University's Animal Agriculture Initiative Coalition for their support of this study.

\section{Publication history}

Editor: Ralf Blank, University of Kiel, Germany. Received: 30-Apr-2015 Final Revised: 11-Jun-2015 Accepted: 03-Jul-2015 Published: 14-Jul-2015

\section{References}

1. Kirk RK, Svensmark B, Ellegaard LP and Jensen HE. Locomotive disorders associated with sow mortality in Danish pig herds. J Vet Med A Physiol Pathol Clin Med. 2005; 52:423-8. | Article I PubMed

2. USDA. Swine 2006, Part 1: Reference of swine health and management practices in the United States, 2006. USDA:APHIS:VS 2007. 2007. I Pdf

3. Dewey CE, Friendship RM and Wilson MR. Clinical and postmortem examination of sows culled for lameness. Can Vet J. 1993; 34:555-6. | PubMed Abstract | PubMed Full Text

4. Goldring $\mathrm{MB}$ and Berenbaum $\mathrm{F}$. The regulation of chondrocyte function by proinflammatory mediators: prostaglandins and nitric oxide. Clin Orthop Relat Res. 2004; S37-46. | Article | PubMed

5. Scher JU, Pillinger $\mathrm{MH}$ and Abramson SB. Nitric oxide synthases and osteoarthritis. Curr Rheumatol Rep. 2007; 9:9-15. | Article | PubMed

6. Mastbergen SC, Bijlsma JW and Lafeber FP. Synthesis and release of human cartilage matrix proteoglycans are differently regulated by nitric oxide and prostaglandin- $\mathrm{E}_{2}$. Ann Rheum Dis. 2008; 67:52-8. | Article | PubMed

7. Alexander JW. Immunonutrition: the role of omega-3 fatty acids. Nutrition. 1998; 14:627-33. | Article | PubMed

8. Razzak A, Aldrich C, Babcock TA, Saied A and Espat NJ. Attenuation of iNOS in an LPS-stimulated macrophage model by omega- 3 fatty acids is independent of COX-2 derived PGE ${ }_{2}$. J Surg Res. 2008; 145:244-50. | Article I PubMed

9. Rosselot G, Reginato AM and Leach RM. Development of a serum-free system to study the effect of growth hormone and insulinlike growth factor-I on cultured postembryonic growth plate chondrocytes. In Vitro Cell Dev Biol. 1992; 28A:235-44. | $\underline{\text { Article | PubMed }}$

10. Chandrasekhar S, Esterman MA and Hoffman HA. Microdetermination of proteoglycans and glycosaminoglycans in the presence of guanidine hydrochloride. Anal Biochem. 1987; 161:103-8. I Article I PubMed 
Robison et al. Veterinary Medicine and Animal Sciences 2015, http://www.hoajonline.com/journals/pdf/2054-3425-3-4.pdf

11. Blanco FJ, Ochs RL, Schwarz H and Lotz M. Chondrocyte apoptosis induced by nitric oxide. Am J Pathol. 1995; 146:75-85. | PubMed Abstract | PubMed Full Text

12. Wann AK, Mistry J, Blain EJ, Michael-Titus AT and Knight MM. Eicosapentaenoic acid and docosahexaenoic acid reduce interleukin1beta-mediated cartilage degradation. Arthritis Res Ther. 2010; 12:R207. | Article | PubMed Abstract | PubMed Full Text

13. Zainal Z, Longman AJ, Hurst S, Duggan K, Caterson B, Hughes CE and Harwood JL. Relative efficacies of omega-3 polyunsaturated fatty acids in reducing expression of key proteins in a model system for studying osteoarthritis. Osteoarthritis Cartilage. 2009; 17:896-905. | Article | PubMed

14. Chan PS, Caron JP and Orth MW. Short-term gene expression changes in cartilage explants stimulated with interleukin beta plus glucosamine and chondroitin sulfate. J Rheumatol. 2006; 33:1329-40 | Article | PubMed

15. Wada M, DeLong CJ, Hong YH, Rieke CJ, Song I, Sidhu RS, Yuan C, Warnock M, Schmaier AH, Yokoyama C, Smyth EM, Wilson SJ, FitzGerald GA, Garavito RM, Sui de X, Regan JW and Smith WL. Enzymes and receptors of prostaglandin pathways with arachidonic acid-derived versus eicosapentaenoic acid-derived substrates and products. J Biol Chem. 2007; 282:22254-66. | Article | PubMed

16. Priante G, Musacchio E, Pagnin E, Calo LA and Baggio B. Specific effect of arachidonic acid on inducible nitric oxide synthase mRNA expression in human osteoblastic cells. Clin Sci (Lond). 2005; 109:177-82. | PubMed

17. Komatsu W, Ishihara K, Murata M, Saito $\mathrm{H}$ and Shinohara K. Docosahexaenoic acid suppresses nitric oxide production and inducible nitric oxide synthase expression in interferon-gamma plus lipopolysaccharide-stimulated murine macrophages by inhibiting the oxidative stress. Free Radic Biol Med. 2003; 34:1006-16. | Article | PubMed

18. Ringbom T, Huss U, Stenholm A, Flock S, Skattebol L, Perera P and Bohlin L. Cox-2 inhibitory effects of naturally occurring and modified fatty acids. J Nat Prod. 2001; 64:745-9. | Article | PubMed

19. Massaro M, Habib A, Lubrano L, Del Turco S, Lazzerini G, Bourcier T, Weksler BB and De Caterina R. The omega-3 fatty acid docosahexaenoate attenuates endothelial cyclooxygenase- 2 induction through both NADP(H) oxidase and PKC epsilon inhibition. Proc Natl Acad Sci U S A. 2006; 103:15184-9. | Article | PubMed Abstract | PubMed Full Text

20. Kuratko CN and Salem N, Jr. Biomarkers of DHA status. Prostaglandins Leukot Essent Fatty Acids. 2009; 81:111-8. | Article | PubMed

21. O'Connor-Robison $\mathrm{Cl}$, Spencer JD and Orth MW. The impact of dietary long-chain polyunsaturated fatty acids on bone and cartilage in gilts and sows. J Anim Sci. 2014; 92:4607-15. | Article | PubMed

Robison CI and Orth MW. Eicosapentaenoic acid and docosahexaenoic acid moderate inflammation in porcine cartilage explants. Vet Med Anim Sci. 2015; 3:4. http://dx.doi.org/10.7243/2054-3425-3-4 